\title{
VARIABLES DIFFERENTIATING POSITIVE HEALTH PROFILES AND SURVIVAL ABILITIES AMONG UKRAINIAN STUDENTS ATTENDING POST-SECONDARY MEDICAL SCHOOL
}

\section{ZMIENNE RÓŻNICUJĄCE PROFILE ZDROWIA POZYTYWNEGO I ZDOLNOŚCI PRZETRWANIA UKRAIŃSKIEJ MLODZIEŻY STUDIUM MEDYCZNEGO}

\author{
Oleksandr Oliynyk ${ }^{1(\mathrm{~A}, \mathrm{D}, \mathrm{E})}$, Anatolii Tsos ${ }^{2(\mathrm{~A}, \mathrm{~B})}$, Józef Bergier $^{3(\mathrm{~A}, \mathrm{C}, \mathrm{D}, \mathrm{E}, \mathrm{F}, \mathrm{G})}$, Dorota Tomczyszyn ${ }^{3(\mathrm{~A}, \mathrm{C}, \mathrm{D}, \mathrm{E}, \mathrm{F})}$
}

${ }^{1}$ I. Horbachevsky Ternopil State Medical University, Ukraine

${ }^{2}$ Lesya Ukrainka Eastern European National University, Lutsk, Ukraine

${ }^{3}$ Pope John Paul II State School of Higher Education in Biała Podlaska, Poland

Authors' contribution Wkład autorów: A. Study design/planning zaplanowanie badań B. Data collection/entry zebranie danych C. Data analysis/statistics dane - analiza i statystyki D. Data interpretation interpretacja danych E. Preparation of manuscript przygotowanie artykułu F. Literature analysis/search wyszukiwanie i analiza literatury G. Funds collection zebranie funduszy

\section{Summary}

Background. Contemporary studies of health and evaluation attempts emphasize the holistic approach to health and its dimensions. The objective of the study was determination of health profiles and survival abilities among adolescents, and indicate differentiating variables. Material and methods. A diagnostic survey was used based on Kalina, investigating the subjective sense of health from the aspects of somatic, mental, social health and survival abilities. SPHSA was calculated as the arithmetic mean of individual health and total health measures. The study was conducted in 2014, in a group of 507 school adolescents aged 15-25 attending Medical Post-Secondary School in Lutsk, Ukraine.

Results. Social health was evaluated by the adolescents in the most positive terms - $3.82( \pm 0.67)$, whereas survival abilities - in the most negative terms, 2.63 $( \pm 0.75)$. In the domain of total health, the highest values occurred for daily physical activity $-3.10( \pm 0.35)$, while the lowest - for occasional activity $-2.78( \pm 0.35)$. Similarly, significant differences were found between adolescents of the final, fourth year of school $(2.82 \pm 0.73)$, and younger students. Significant correlations were demonstrated $(\mathrm{p}<0.05)$ in individual health profiles. With regard to survival capability, such correlation was observed in adolescents engaged in daily physical activity and students from big cities. In the somatic health profile it was observed in overweight adolescents and those who showed systematic physical activity and in the survival capability profile of adolescents pursuing systematic physical activity. With regard to the social health profile a significantly higher value occurred in first-year students and those with the highest educational achievements.

Conclusions. The results of the study obtained should be used in discussions concerning educational programmes for students of paramedical specialties in the Ukraine.

Keywords: health profile, period of adolescence, SPHSA questionnaire

\section{Streszczenie}

Wprowadzenie. Współcześnie w badaniach nad zdrowiem i próbach jego oceny wskazuje się na holistyczne traktowanie zdrowia i jego wymiarów. Celem pracy było scharakteryzowanie specyfiki profili zdrowia i zdolności przetrwania wśród młodzieży oraz wskazanie zmiennych je różnicujących.

Materiał i metody. Zastosowano metode sondażu diagnostycznego na postawie oryginalnej metodologii Kaliny, która polega na badaniu subiektywnego poczucia zdrowia w zakresie czterech mierników: zdrowia somatycznego, psychicznego, społecznego i zdolności przetrwania. Indeks SPHSA obliczono za pomocą średniej arytmetycznej poszczególnych mierników zdrowia i zdrowia całkowitego. Badania zrealizowano w 2014 r., na grupie 507 uczniów w wieku 15-25 lat będących słuchaczami studium policealnego w Łucku na Ukrainie.

Wyniki. Młodzież najwyżej oceniła swoje zdrowie społeczne $3,82( \pm 0,67)$, natomiast najniżej zdolności przetrwania 2,63 $( \pm 0,75)$. Wkategorii zdrowia całkowitego istotnienajwyższewartościzaobserwowano u uczniów o codziennej aktywności ruchowej 3,10( $\pm 0,35)$, a najniższe wystapiły u rówieśników o aktywności sporadycznej $2,78( \pm 0,35)$. Podobnie istotne różnice wykazano między uczniami ostatniej czwartejklasy $(2,82 \pm 0,73)$,aklasamimłodszymi. Wykazano istotnezależności $(\mathrm{p}<0,05$ wposzczególnych profilach zdrowia. W zdolności przetrwania taki związek wystąpił u uczniów o codziennej aktywności ruchowej oraz u uczniów $\mathrm{z}$ dużych miast. $\mathrm{W}$ profilu zdrowia somatycznego $\mathrm{w}$ grupie uczniów $\mathrm{z}$ nadwagą i u osób o systematycznej aktywności fizycznej, a także w profilu zdolności przetrwania u uczniów o systematycznej aktywności fizycznej. W profilu zdrowia społecznego istotnie wyższą wartość wykazano u uczniów pierwszego roku studiów i najwyższych osiągnięciach edukacyjnych. Wnioski. Uzyskane wyniki badań powinny być wykorzystane w dyskusjach nad programami kształcenia młodzieży na kierunkach paramedycznych na Ukrainie.

Słowa kluczowe: profile zdrowia, okres dojrzewania, test SPHSA
Figures: 0

References: 21

Submitted: 2017 Jan 19

Accepted: 2017 Feb 01

Oliynyk 0, Tsos A, Bergier J, Tomczyszyn D. Variables differentiating positive health profiles and survival abilities among Ukrainian students attending Post-Secondary Medical School. Health Problems of Civilization. 2017; 11(1): 23-31. doi: 10.5114/hpc.2017.65525.

Address for correspondence / Adres korespondencyjny: Dorota Tomczyszyn, Pope John Paul II State School of Higher Education in Biała Podlaska, Sidorska 95/97, 21-500 Biała Podlaska, Poland, e-mail: tomczyszyn@o2.pl, phone: +48 833449900

Copyright: (c) 2017 Pope John Paul II State School of Higher Education in Biała Podlaska, Oleksandr Oliynyk, Anatolii Tsos, Józef Bergier, Dorota Tomczyszyn. This is an Open Access journal, all articles are distributed under the terms of the Creative Commons Attribution-NonCommercial-ShareAlike 4.0 International (CC BY-NCSA 4.0) License (http://creativecommons.org/licenses/by-nc-sa/4.0/), allowing third parties to copy and redistribute the material in any medium or format and to remix, transform, and build upon the material, provided the original work is properly cited and states its license. 


\section{Background}

Contemporary health education derived mainly from medical sciences, often extends to the social sciences. It is noteworthy that many years ago Demel and Zuchora paid attention to the role of health culture as a system of values related with physical and mental health [1].

The concept of health is difficult to define precisely, and more than a hundred expressions may be found in literature [2]. It is worth paying attention to the definition of health in the Constitution of the World Health Organization, adopted by the WHO in 1946 - when as early as at that time, the importance of a subjective evaluation of health was emphasized. Problems with the evaluation (measurements) of health contribute to the difficulties with its definition. In the contemporary evaluation of health, objective measures (measurable) and subjective measures (performed by non-professionals) are distinguished.

In the studies of health and attempts to evaluate it, Mazur [3] indicated various dimensions of health including, among others, physical, mental, and social health. The holistic approach to health considers all the possible aspects and connections [4]. The holistic model of health distinguishes several dimensions of health: physical, mental, social, sexual, spiritual, and emotional, which are embraced by the health of society and environmental health [5].

According to Woynarowska [2], health means a certain type of balance between its individual dimensions. The researcher distinguishes physical health (related with the body and biological functioning of the organism), social health, spiritual health, and sexual health.

A similar definition of health was presented by Eriksson and Lindstrom, who differentiated its several dimensions: physical health, also called somatic, mental, social, spiritual, and environmental [6].

Kalina, proposed his methodology for the evaluation of health by defining the following aspects of health: somatic, mental, social, and a new proposal - survival ability, which jointly determine total health (overall health) [7].

In literature, physical health (somatic) has been most comprehensively described as a type of foundation for other aspects of health. The state of physical health is specified by various indicators, including those related to the evaluation of physical activity. It is noteworthy that the data published by the WHO in 2010 indicate that low physical activity occupies the fourth position among factors leading to human death [8].

In recent years in Poland, the scope of problems related with this important aspect has been undertaken in concern of human health, based on a relatively representative research material, using the IPAQ $[9,10,11]$, and in many countries $[12,13,14,15,16]$.

In the studies underlying the presented article the International Physical Activity Questionnaire (IPAQ) was also applied. This instrument is commonly recommended, and the results of studies enable current control and formulation of recommendations for a health promoting life style.

The studies conducted to-date have confirmed that the period of adolescence decides about our health in adulthood $[17,18]$, and the presented study also refers to this period.

\section{Objective}

The objective of this study was to determine the specificity of health profiles and survival abilities among school adolescents, and identify the variables according to which significant differences are observed.

\section{Material and method}

The study was conducted in 2014, in a group of 507 school adolescents aged 15-25, attending the Post-Secondary Medical College in Lutsk, Ukraine. The method of a diagnostic survey was used, based on the original methodology by Kalina: The Sense of Positive Health and Survival Abilities (SPHSA) [7]. The applied method is based on the investigation of the subjective sense of health in the area of four dimensions: somatic health, mental health, social health, and the survival ability. The sense of intensity of individual indicators was evaluated according to the scale from 1 - 5 (scoring as follows: 1 - very low, 2 - low, 3 - mediocre, 4 - high, 5 - very high). The SPHSA Index was calculated by means of an arithmetic mean calculated for individual measures of health, and total health as a sum of particular measures of health.

The respondents were mainly females $(92.1 \%)$, while males constituted $7.9 \%$. More than a half of school adolescents in the study were aged 18 and over (53.7\%), whereas the remainder (46.4\%) were aged from 15 - 17. More than a half of the group examined lived in rural areas (51.7\%), and nearly a half - in urban areas, including $24.7 \%$ of inhabitants of big cities with the population of over 200,000 . The greatest majority of school adolescents lived in a block of flats (71.2\%). The largest number of respondents had a normal body weight (75\%), followed by those underweight (18.2\%), and overweight (6.9\%). Most frequently, the adolescents participated in physical education classes once a week (63.3\%) (Table 1$)$. 
Table 1. Characteristics of school adolescents in the study

\begin{tabular}{|l|rr|}
\hline \multicolumn{1}{|c|}{ Variable } & Number (n) & Structure (\%) \\
\hline Gender & 40 & 7.89 \\
Males & 467 & 92.11 \\
Females & & 46.35 \\
\hline Age & 235 & 53.65 \\
15-17 & 272 & 51.68 \\
18-25 & & 24.65 \\
\hline Place of residence & 262 & 23.67 \\
Rural area & 125 & 71.20 \\
City with population up to 200,000 & 120 & 28.80 \\
City with population of over 200,000 & & 18.15 \\
\hline Residential building & 361 & 74.95 \\
Block of flats & 146 & 6.90 \\
House & & 22.88 \\
\hline BMI Classification & 92 & 63.31 \\
Underweight & 380 & 13.81 \\
Normal weight & 35 & \\
Overweight & 116 & \\
\hline Physical activity & 321 & \\
Occasional & 70 & \\
Once a week & & \\
Daily activity & & \\
\hline
\end{tabular}

The examined adolescents continued education in five specialties: medical $-30.4 \%$, nursing $-27.4 \%$, pharmacy - 17\%, midwifery - 15.2\%, and laboratory diagnostics - 10.1\%. Educational achievements of the majority of respondents were evaluated as good (57.4\%), while every fourth school adolescent obtained satisfactory education results (24.5\%), and $18.1 \%$ - very good results (Table 2 ).

Table 2. Information concerning respondents' education

\begin{tabular}{|l|cc|}
\hline \multicolumn{1}{|c|}{ Variable } & Number (n) & Structure (\%) \\
\hline Specialty & 86 & 16.96 \\
Pharmacy & 154 & 30.37 \\
Medicine & 77 & 15.19 \\
Midwifery & 139 & 27.42 \\
Nursing & 51 & 10.06 \\
Laboratory diagnostics & & 21.70 \\
\hline Year of education & 110 & 31.36 \\
First & 159 & 28.80 \\
Second & 146 & 18.15 \\
Third & 92 & 24.46 \\
Fourth & & 57.40 \\
\hline Educational achievements & 124 & 18.14 \\
Satisfactory & 291 & 92 \\
Good & 92 & \\
Very good & & \\
\hline
\end{tabular}

\section{Statistical methods}

Arithmetic means and standard deviations were calculated for individual domains of health, as well as minimum and maximum values, and coefficients of variation in percentages (V\%). The following tests were applied in the study: non-parametric Friedman test, Kruskal-Wallis test, and Mann-Whitney test. The Friedman test was used to 
compare health profiles of school adolescents in individual educational specialties. The Kruskal-Wallis test was applied to investigate the relationship between health profiles and educational specialties, place of residence, BMI index, physical activity, year of education, educational achievements (more than two independent variables). The Mann-Whitney U test was used to examine indicators for two independent samples, i.e. age group and type of residential building. The $\mathrm{p}$ values $\mathrm{p}<0.05$ were considered statistically significant.

\section{Results}

\section{Level of health profiles}

The adolescents in the study evaluated their social health in most positive terms $3.82( \pm 0.67)$, whereas survival abilities - in most negatives terms $2.63( \pm 0.75)$. Considering educational specialties, significant differences $(\mathrm{p}<0.05)$ were found in two dimensions: mental health and survival abilities. With respect to mental health, the highest value of the indicator was observed among school adolescents attending the class with maternity profile $3.01( \pm 0.46)$, while the lowest in the nursing specialty $2.78( \pm 0.60)$. In the dimension of survival ability, the highest value of the indicator was obtained by adolescents who studied nursing, whereas the lowest value was noted in the specialty of pharmacy (2.46) $(\leq 0.64)$ (Table 3$)$.

Table 3. Levels of health profiles of school adolescents in various specialties

\begin{tabular}{|c|c|c|c|c|c|c|c|}
\hline \multirow{2}{*}{\multicolumn{2}{|c|}{ Specialty }} & \multicolumn{5}{|c|}{ Health profile } & \multirow{2}{*}{$\begin{array}{c}\text { Friedman } \\
\text { Test }\end{array}$} \\
\hline & & Somatic health & Mental health & Social health & Survival ability & Total health & \\
\hline \multirow{5}{*}{$\begin{array}{c}\text { Total } \\
(\mathrm{n}=507)\end{array}$} & $\bar{x}$ & 2.90 & 2.86 & 3.82 & 2.63 & 2.92 & \multirow{5}{*}{$\begin{array}{c}F=168.58 \\
p<0.0001^{*}\end{array}$} \\
\hline & $S D$ & 0.38 & 0.59 & 0.67 & 0.75 & 0.36 & \\
\hline & $x_{\min }$ & 1.50 & 0.50 & 1.00 & 0.38 & 1.65 & \\
\hline & $x_{\max }$ & 4.00 & 4.50 & 5.00 & 4.63 & 4.13 & \\
\hline & $V_{\%}$ & 13.20 & 20.75 & 17.61 & 28.43 & 12.47 & \\
\hline \multirow{5}{*}{$\begin{array}{l}\text { Pharmacy } \\
(n=86)\end{array}$} & $\bar{x}$ & 2.89 & 2.90 & 3.74 & $2.46^{\mathrm{Pi}}$ & 2.85 & \multirow{5}{*}{$\begin{array}{c}F=132.50 \\
p<0.0001^{*}\end{array}$} \\
\hline & $S D$ & 0.41 & 0.70 & 0.75 & 0.64 & 0.36 & \\
\hline & $x_{\min }$ & 1.75 & 1.00 & 1.00 & 1.00 & 2.00 & \\
\hline & $x_{\max }$ & 4.00 & 4.50 & 5.00 & 4.00 & 3.78 & \\
\hline & $V_{\%}$ & 14.08 & 24.26 & 20.02 & 25.90 & 12.62 & \\
\hline \multirow{5}{*}{$\begin{array}{l}\text { Medicine } \\
(\mathrm{n}=154)\end{array}$} & $\bar{x}$ & 2.94 & 2.83 & 3.79 & 2.70 & 2.95 & \multirow{5}{*}{$\begin{array}{c}F=47.15 \\
p<0.0001 *\end{array}$} \\
\hline & $S D$ & 0.37 & 0.57 & 0.68 & 0.76 & 0.36 & \\
\hline & $x_{\min }$ & 1.50 & 1.25 & 2.00 & 0.63 & 1.83 & \\
\hline & $x_{\max }$ & 4.00 & 4.25 & 5.00 & 4.63 & 4.13 & \\
\hline & $V_{\%}$ & 12.76 & 20.07 & 17.88 & 28.21 & 12.21 & \\
\hline \multirow{5}{*}{$\begin{array}{l}\text { Midwifery } \\
(\mathrm{n}=77)\end{array}$} & $\bar{x}$ & 2.85 & $3.01^{\mathrm{Pi}}$ & 3.85 & $2.47^{\mathrm{Pi}}$ & 2.88 & \multirow{5}{*}{$\begin{array}{c}\mathrm{F}=44.41 \\
\mathrm{p}<0.0001\end{array}$} \\
\hline & $S D$ & 0.35 & 0.46 & 0.49 & 0.74 & 0.35 & \\
\hline & $x_{\min }$ & 2.00 & 1.25 & 2.67 & 0.50 & 1.96 & \\
\hline & $x_{\max }$ & 3.75 & 4.00 & 5.00 & 3.88 & 3.70 & \\
\hline & $V_{\%}$ & 12.38 & 15.34 & 12.84 & 30.04 & 12.17 & \\
\hline \multirow{5}{*}{$\begin{array}{l}\text { Nursing } \\
(\mathrm{n}=139)\end{array}$} & $\bar{x}$ & 2.87 & $2.78^{\mathrm{Po}}$ & 3.95 & $2.81^{\text {F.Po }}$ & 2.98 & \multirow{5}{*}{$\begin{array}{c}\mathrm{F}=44.41 \\
\mathrm{p}<0.0001\end{array}$} \\
\hline & $S D$ & 0.40 & 0.60 & 0.66 & 0.74 & 0.38 & \\
\hline & $x_{\min }$ & 1.50 & 1.25 & 2.00 & 0.75 & 1.65 & \\
\hline & $x_{\max }$ & 3.75 & 4.00 & 5.00 & 4.63 & 3.83 & \\
\hline & $V_{\%}$ & 13.84 & 21.53 & 16.67 & 26.50 & 12.86 & \\
\hline \multirow{5}{*}{$\begin{array}{l}\text { Laboratory } \\
\text { diagnostics } \\
\qquad(n=51)\end{array}$} & $\bar{x}$ & 2.97 & 2.88 & 3.67 & 2.49 & 2.88 & \multirow{5}{*}{$\begin{array}{c}\mathrm{F}=44.41 \\
\mathrm{p}<0.0001^{*}\end{array}$} \\
\hline & $S D$ & 0.36 & 0.60 & 0.76 & 0.79 & 0.34 & \\
\hline & $x_{\min }$ & 2.13 & 0.50 & 1.67 & 0.38 & 1.78 & \\
\hline & $x_{\max }$ & 3.63 & 3.75 & 4.67 & 3.88 & 3.35 & \\
\hline & $V_{\%}$ & 12.25 & 20.99 & 20.65 & 31.66 & 11.64 & \\
\hline \multirow{2}{*}{$\begin{array}{c}\text { Kruskal-Wallis } \\
\text { Test }\end{array}$} & $\mathrm{H}$ & 7.56 & 14.56 & 7.66 & 17.30 & 9.54 & \multirow[b]{2}{*}{-} \\
\hline & $\mathrm{p}$ & 0.1093 & $0.0057^{*}$ & 0.1050 & $0.0017^{*}$ & $0.0490 *$ & \\
\hline
\end{tabular}

specialty: F- Pharmacy. M-Medicine. Po- Midwifery. Pi- Nursing. D-Laboratory diagnostics

*- significant differences at $\mathrm{p}<0.05$ 


\section{Demographic characteristics (age, place of residence, type of residence) and health profile}

A significant relationship was found only between the place of residence and survival abilities. The highest values of this indicator were noted in respondents from big cities (population over 200,000), while the lowest among their contemporaries from rural areas $2.56( \pm 0.75)$. However, no differences were observed according to the respondents' age and type of residence (block of flats, family house) (Table 4).

Table 4. Level of school adolescents' profiles with condsideration of demographic characteristics

\begin{tabular}{|c|c|c|c|c|c|c|}
\hline \multirow{2}{*}{\multicolumn{2}{|c|}{ Variable }} & \multicolumn{5}{|c|}{ Health profile } \\
\hline & & $\begin{array}{c}\text { Somatic } \\
\text { health }\end{array}$ & $\begin{array}{l}\text { Mental } \\
\text { health }\end{array}$ & $\begin{array}{l}\text { Social } \\
\text { health }\end{array}$ & $\begin{array}{c}\text { Survival } \\
\text { ability }\end{array}$ & $\begin{array}{c}\text { Total } \\
\text { health }\end{array}$ \\
\hline \multirow{2}{*}{$\begin{array}{l}\text { Total } \\
(n=507)\end{array}$} & $\bar{x}$ & 2.90 & 2.86 & 3.82 & 2.63 & 2.92 \\
\hline & $S D$ & 0.38 & 0.59 & 0.67 & 0.75 & 0.36 \\
\hline \multicolumn{7}{|l|}{ Age } \\
\hline \multirow{2}{*}{$\begin{array}{l}15-17 \\
(n=235)\end{array}$} & $\bar{x}$ & 2.90 & 2.82 & 3.81 & 2.61 & 2.91 \\
\hline & $S D$ & 0.38 & 0.58 & 0.68 & 0.76 & 0.36 \\
\hline \multirow{2}{*}{$\begin{array}{l}18-25 \\
(n=272)\end{array}$} & $\bar{x}$ & 2.90 & 2.90 & 3.84 & 2.65 & 2.93 \\
\hline & $S D$ & 0.38 & 0.60 & 0.67 & 0.74 & 0.37 \\
\hline \multirow{2}{*}{ Mann-Whitney U Test } & $\mathrm{Z}$ & 0.023 & 1.82 & 0.40 & 0.64 & 0.86 \\
\hline & $\mathrm{p}$ & 0.9764 & 0.0688 & 0.6902 & 0.5217 & 0.3916 \\
\hline \multicolumn{7}{|l|}{ Place of residence } \\
\hline \multirow{2}{*}{$\begin{array}{l}\text { Rural area } \\
(n=262)\end{array}$} & $\bar{x}$ & 2.89 & 2.85 & 3.83 & $2.56^{3}$ & 2.89 \\
\hline & $S D$ & 0.37 & 0.56 & 0.68 & 0.75 & 0.36 \\
\hline \multirow{2}{*}{$\begin{array}{l}\text { City with population up to } \\
200,000(\mathrm{n}=125)\end{array}$} & $\bar{x}$ & 2.87 & 2.89 & 3.84 & 2.62 & 2.91 \\
\hline & $S D$ & 0.42 & 0.63 & 0.62 & 0.79 & 0.38 \\
\hline \multirow{2}{*}{$\begin{array}{l}\text { City with population of over } \\
200,000(n=120)\end{array}$} & $\bar{x}$ & 2.96 & 2.84 & 3.78 & $2.81^{1}$ & 3.00 \\
\hline & $S D$ & 0.36 & 0.63 & 0.72 & 0.68 & 0.34 \\
\hline \multirow{2}{*}{ Kruskal-Wallis Test } & $\mathrm{H}$ & 4.44 & 2.19 & 0.22 & 10.61 & 5.49 \\
\hline & $\mathrm{p}$ & 0.1083 & 0.3346 & 0.8961 & $0.0050 *$ & 0.0644 \\
\hline \multicolumn{7}{|l|}{ Residential building } \\
\hline \multirow{2}{*}{$\begin{array}{l}\text { Block of flats } \\
(n=361)\end{array}$} & $\bar{x}$ & 2.91 & 2.88 & 3.83 & 2.63 & 2.93 \\
\hline & $S D$ & 0.37 & 0.57 & 0.68 & 0.71 & 0.34 \\
\hline \multirow{2}{*}{$\begin{array}{l}\text { House } \\
(n=143)\end{array}$} & $\bar{x}$ & 2.87 & 2.82 & 3.79 & 2.63 & 2.90 \\
\hline & $S D$ & 0.42 & 0.66 & 0.65 & 0.83 & 0.41 \\
\hline \multirow{2}{*}{ Mann-Whitney U Test } & $\mathrm{Z}$ & 0.72 & 0.47 & 0.80 & -0.1780 & 0.47 \\
\hline & $\mathrm{p}$ & 0.4737 & 0.6392 & 0.4227 & 0.8587 & 0.6356 \\
\hline
\end{tabular}

*- significant differences at $\mathrm{p}<0.05$.

\section{BMI index and physical activity vs. health profiles}

Significant differences were found between BMI index and somatic health, with the highest value of the indicator observed in the group of adolescents with overweight $3.03( \pm 0.43)$, compared to their contemporaries who were underweight $2.81( \pm 0.39$ ) (Table 5). 
Table 5. Level of respondents' health profiles according to BMI and physical activity

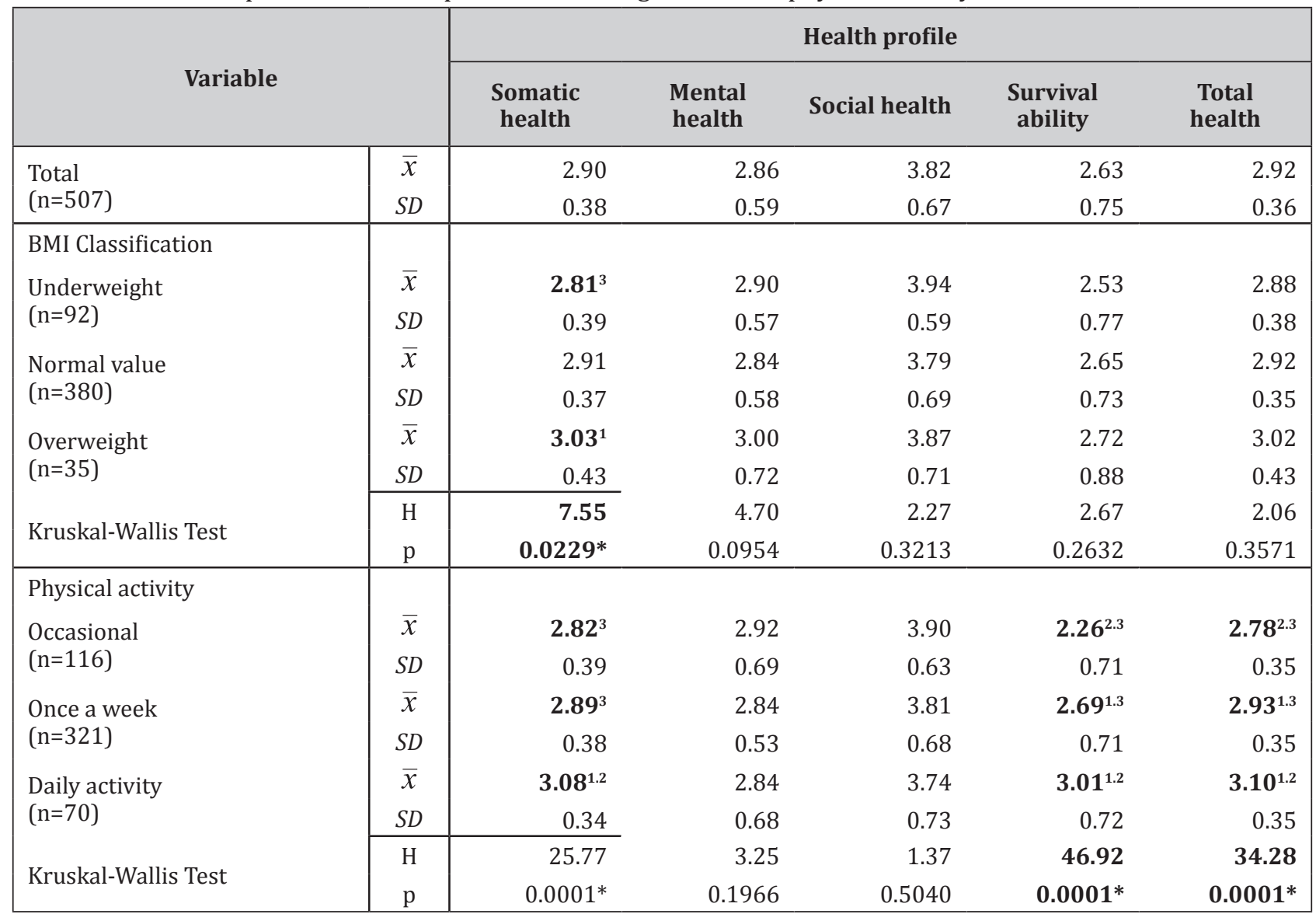

*-significant differences at $\mathrm{p}<0.05$.

Many significant relationships were observed according to the respondents' physical activity. A higher value of the somatic health indicator was noted in school adolescents who showed a systematic (daily) physical activity $3.08( \pm 0.34)$, compared to those who participated in physical activity once a week or occasionally.

With respect to the survival ability, the highest value was significantly more frequently observed in school adolescents involved in daily physical activity $3.01( \pm 0.72)$, compared to their contemporaries who were involved in physical activity once a week or occasionally.

Similarly, significant relationships were confirmed with respect to total health. The highest values of the indicator were found in respondents who showed daily physical activity $3.10( \pm 0.35)$, whereas the lowest among those occasionally engaged in physical activity $2.78( \pm 0.35)$.

\section{Duration of education and educational achievements vs. health profiles}

Significant relationships were observed according to the duration of education. In the domain of social health it was confirmed that the highest value of the indicator occurred during the first year of education $3.96( \pm 0.72$ ), whereas in the domain of survival ability the highest indicator was observed during the last (fourth) year of education $2.82( \pm 0.73)$. It is noteworthy that significant differences were also found with respect to total health, with the highest indicator observed during the fourth year of education $3.02( \pm 0.39)$ (Table 6). 
Table 6. Level of respondents' health profiles according to the year of education and educational achievements

\begin{tabular}{|c|c|c|c|c|c|c|}
\hline \multirow{2}{*}{\multicolumn{2}{|c|}{ Variable }} & \multicolumn{5}{|c|}{ Health profile } \\
\hline & & \multirow{3}{*}{$\begin{array}{r}\begin{array}{l}\text { Somatic } \\
\text { health }\end{array} \\
2.90 \\
0.38\end{array}$} & \multirow{3}{*}{$\begin{array}{r}\begin{array}{l}\text { Mental } \\
\text { health }\end{array} \\
2.86 \\
0.59 \\
\end{array}$} & \multirow{3}{*}{$\begin{array}{r}\begin{array}{c}\text { Social } \\
\text { health }\end{array} \\
3.82 \\
0.67 \\
\end{array}$} & \multirow{3}{*}{$\begin{array}{r}\begin{array}{c}\text { Survival } \\
\text { ability }\end{array} \\
2.63 \\
0.75\end{array}$} & \multirow{3}{*}{$\begin{array}{r}\begin{array}{c}\text { Total } \\
\text { health }\end{array} \\
2.92 \\
0.36\end{array}$} \\
\hline Total & $\bar{x}$ & & & & & \\
\hline$(n=507)$ & $S D$ & & & & & \\
\hline \multicolumn{7}{|l|}{ Year of education } \\
\hline \multirow{2}{*}{ First $(n=110)$} & $\bar{x}$ & 2.93 & 2.82 & $3.96^{3}$ & 2.70 & 2.96 \\
\hline & $S D$ & 0.40 & 0.62 & 0.72 & 0.80 & 0.38 \\
\hline \multirow{2}{*}{ Second $(n=159)$} & $\bar{x}$ & 2.87 & 2.87 & 3.77 & $2.52^{4}$ & $2.87^{4}$ \\
\hline & $S D$ & 0.39 & 0.53 & 0.66 & 0.70 & 0.33 \\
\hline \multirow{2}{*}{ Third $(n=146)$} & $\bar{x}$ & 2.90 & 2.83 & $3.71^{1}$ & 2.59 & $2.89^{4}$ \\
\hline & $S D$ & 0.37 & 0.62 & 0.59 & 0.74 & 0.36 \\
\hline \multirow{2}{*}{ Fourth $(n=92)$} & $\bar{x}$ & 2.92 & 2.94 & 3.93 & $2.82^{2}$ & $3.02^{2.3}$ \\
\hline & $S D$ & 0.37 & 0.61 & 0.72 & 0.73 & 0.39 \\
\hline \multirow{2}{*}{ Kruskal-Wallis Test } & $\mathrm{H}$ & 1.63 & 2.95 & 13.12 & 8.75 & 13.16 \\
\hline & $\mathrm{p}$ & 0.6519 & 0.3991 & $0.0044^{*}$ & 0.0328* & $0.0043^{*}$ \\
\hline \multicolumn{7}{|l|}{ Educational achievements } \\
\hline \multirow{2}{*}{$\begin{array}{l}\text { Satisfactory } \\
(n=124)\end{array}$} & $\bar{x}$ & 2.89 & 2.86 & $3.64^{3}$ & 2.68 & 2.91 \\
\hline & $S D$ & 0.35 & 0.62 & 0.72 & 0.75 & 0.35 \\
\hline \multirow{2}{*}{$\begin{array}{l}\text { Good } \\
(n=291)\end{array}$} & $\bar{x}$ & 2.89 & 2.87 & $3.82^{3}$ & 2.58 & 2.90 \\
\hline & $S D$ & 0.40 & 0.59 & 0.66 & 0.74 & 0.36 \\
\hline \multirow{2}{*}{$\begin{array}{l}\text { Very good } \\
(n=92)\end{array}$} & $\bar{x}$ & 2.95 & 2.82 & $4.09^{1.2}$ & 2.74 & 3.00 \\
\hline & $S D$ & 0.38 & 0.58 & 0.56 & 0.76 & 0.37 \\
\hline \multirow{2}{*}{ Kruskal-Wallis Test } & $\mathrm{H}$ & 2.98 & 0.27 & 21.77 & 3.58 & 5.17 \\
\hline & $\mathrm{p}$ & 0.2248 & 0.8758 & $0.0001^{*}$ & 0.1674 & 0.0753 \\
\hline
\end{tabular}

*- significant differences at $\mathrm{p}<0.05$.

Considering the educational achievements of school adolescents, significant relationships were confirmed only in the domain of social health, with the highest value of the indicator noted in adolescents who had very good educational achievements $4.09( \pm 0.56)$, followed by good educational achievements $3.82( \pm 0.66)$, while the lowest - in the group with satisfactory education results $3.64( \pm 0.72)$.

\section{Discussion}

Based on the to-date application of the analyzed questionnaire [7] among university students was found that the overall health index indicator remained within the range of values from 3.50-3.80, with the highest values observed in the specialty of nursing -3.79 , followed by public health 3.78 [19], and tourism and recreation -3.74 [20]. The value of this indicator among the school adolescents examined was clearly lower $2.92( \pm 0.36)$, which may result from their poorer knowledge of the problems of health, compared to the examined students.

In the case of assessment of health profiles, the school adolescents evaluated their social health in most positive terms 3.82 ( \pm 0.67$)$. Similar evaluations were expressed by students of medical specialties 4.38 ( \pm 0.63 ) [19] students of physiotherapy $4.14( \pm 0.59)$ [7], and students of tourism and recreation $4.08( \pm 0.52)$ [20].

Students at the University of Physical Education evaluated the level of their survival abilities in the most negative terms $[7,20]$. The school adolescents in the study also obtained the lowest indicators in the survival abilities profile. It is probable that knowledge concerning survival abilities among adolescents, both school children and university students, still remains too superficial. Different results were obtained in the group of students of paramedical specialities, who expressed the most negative evaluations concerning their mental health [19].

Analysis of the relationship between various variables and the level of overall health indicator reported by school children did not show unequivocal regularities. Significant relationships were observed according to the duration of education and systematic participation in physical activity. Such relationships were confirmed among school adolescents in the final class, i.e. during the fourth year of education, which should be explained by knowledge acquired at the final stage of education. 
It should be welcomed with satisfaction that the overall health indicator was significantly higher in the group of school adolescents who showed the highest, i.e. daily physical activity. It may be presumed with a high probability that the exemplary attitude of school adolescents with respect to physical activity distinguishes them from their contemporaries by a higher valuation of total health. However, no such relationships were found according to age, place and type of residence, BMI index, and educational achievements. Nevertheless, it should be noted that a number of relationships were confirmed between the seven factors analyzed and individual health profiles.

Considering the fact that social health obtained the highest values among the school adolescents in the study, it is worth analyzing according to which variables the differences are significant, and attempt to explain these mechanisms. Such significant relationships were observed with respect to educational achievements, where adolescents who obtained the best education results evaluated this aspect of health in the most positive terms. Thus, it may be presumed that a higher knowledge resulting from very good educational achievements exerts an effect on the special valuation of social health. Such a significant relationship was also noted between the duration of education and value of the social health indicator. It is probably a surprising fact that school adolescents in the first year of education evaluated their social health significantly higher than those in the second and third years of education. Perhaps this is the result of previously acquired knowledge or experiences brought from the family environment concerning the role of social health.

Considering the three demographic characteristics analyzed, a significant relationship was confirmed between the place of residence in a big city, and the survival abilities profile. It may be presumed that the place of residence in large urban settlements, to a higher degree than in the rural environment, provides knowledge about survival abilities. The largest number of relationships was observed between systematic physical activity and such health profiles as: somatic health, survival abilities, and previously mentioned total health.

It is worth mentioning that significant relationships were also found in the domain of somatic health, with the BMI index being the highest in the group of school adolescents who were overweight. It may be presumed with a high probability that the health problem of overweight triggers in them a greater concern about their silhouette and consequently, a higher evaluation of the somatic health profile.

In turn, in the area of the social health profile, significant relationships were revealed with respect to high educational achievements. Thus, it may be presumed that adolescents' knowledge contributes to its special valuation.

\section{Conclusions}

The results obtained enabled the recognition of health profiles by a new social group of post-secondary school adolescents. Of special value is the fact that these were opinions expressed by adolescents in typical paramedical specialties: pharmacy, medicine, midwifery, nursing, and laboratory diagnostics. Considering the fact that in the near future the Ukraine will undergo many transformations, including the system of school and university education, it may be presumed that these results will be very useful. Tsos et al. pay attention to the use of study results in the area of paramedical specialties in the Ukraine [21].

\section{References:}

1. Demel M, Zuchora K. Cele kształcenia i wychowania fizycznego zdrowotnego. Kultura Fizyczna 1975; 4: 146149 (in Polish).

2. Woynarowska B., editor. Edukacja Zdrowotna. Warszawa: Wydawnictwo Naukowe PWN; 2007 (in Polish).

3. Mazur J. Pomiar jakości życia. In: Brzeziński ZJ., editor. Horyzonty metodyczne w epidemiologii. Warszawa: Komisja Epidemiologii i Zdrowia Publicznego. Wydział Nauk Medycznych PAN; 2005 (in Polish).

4. Surzykiewicz J. Holizm. In: Pilch T., editor. Encyklopedia pedagogiczna XXI wieku. Tom 2, Warszawa: Wydawnictwo Akademickie Żak; 2003 (in Polish).

5. Simovska V, Jensen BB, Carlsson M, Albeck Ch. Shape up Europe. Towards a healthy and balanced growing up, Barcelona, P.A.U. Publisher [cited 2017 Jan 10]. Available from: www.shapeupeurope.net.

6. Eriksson I, Lindström A. Salutogenic interpretation of the Ottawa Charter. Health Promot. Int. 2008; 23(2): 190-199.

7. Kalina RM. The profile of sense of Positive Health and Survival Abilities indices (subjective assessment) as a diagnostic tool used in health-related training. Arch Budo, 2012; 8(4): 219-224.

8. World Health Organization. Global Recommendations on Physical Activity for Health 2012; [cited 2017 Jan 10]; p. 5-17, Available from: http://www.who.int/dietphysicalactivity/factsheet_recommendations/en/

9. Biernat E. Aktywność fizyczna mieszkańców Warszawy. Na przykładzie wybranych grup zawodowych. Warszawa: Szkoła Główna Handlowa; 2011 (in Polish). 
10. Bergier J, Kapka-Skrzypczak L, Bilinski P, Paprzycki P, Wojtyła A. Physical activity of Polish adolescents and young adults according to IPAQ: a population based study. Ann Agric Environ Med. 2012; 19(1): 109-115.

11. Mynarski W, Rozpara M, Królikowska B, Puciato D, Graczykowska B. Jakościowe i ilościowe aspekty aktywności fizycznej. Studia i Monografie. 2012: 8(4): 313 (in Polish).

12. Bergier B, Bergier J, Wojtyła A. Various aspects of physical activity among Lithuanian adolescents. Annals of Agricultural and Environmental Medicine. 2012: 19(4): 825-829.

13. Mitáš J, Nykodým J, Frömel K. Physical activity and sedentary behaviour in 14-15 year old students with regard to location of school. Acta Univ. Palacki. Olomuc., Gymn. 2009; 39(3): 7-11.

14. Cocca A, Liukkonen J, Mayorga-Vega D, Viciana-Ramirez J. Helath-related physical activity levels in Spanish youth and young adults. Perceptual\&Motor Skills: Physical Development\&Measurement. 2014; 118: $247-260$.

15. Pelegrini A, Silva DAS, Claumann GS, Cardoso TE. Ferreira de Lima e Silva JM, Petroski E. Practice of walking, moderate and vigorous physical activity and associated factors in adolescents from a state capital of southern Brazil. Rev Bras Cineantropom Desempenho Hum. 2014; 17(1):11-20.

16. Paudel S, Subedi N, Bhandari R, Bastola R, Niroula R, Poudyal AK. Estimation of leisure time physical activity and sedentary behaviour among school adolescents in Nepal. BMC. Public Health. 2014; 14: 637.

17. Eriksson JG, Forsen T, Tuomilehto J, Winter PD, Osmond C, Barker DJ. Catch-up growth in childhood and death from coronary heart disease: longitudinal study. BMJ. 1999; 318(7181): 427-431.

18. Plewa M, Markiewicz A. Physical activity in prevention and treatment of obesity. Endocrinology. Obesity Metabolic Disord. 2006; 2: 30-37.

19. Bergier B. The diversity of the profiles involving the sense of positive health and survival abilities of Polish students of paramedical sciences. Archives of Budo. 2015; 11(5): 17-25.

20. Jagiełło W, Sawczyn S, Jagiełło M. et al. The subjective profile of positive health and survival abilities in female students differing as to physical activity. Teoriâ i Praktika Fizičeskoj Kultury; 2013; 5: 15-18.

21. Tsos A, Olejnik A, Szepeluk A. Subjective health profiles among the Ukrainian school youth from medical school, Health Problems of Civilization. 2016; 10(1): 32-38. 